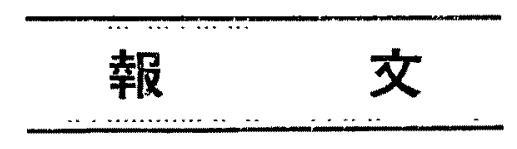

\title{
コム硫黄系誘電體的性質
}

（米國標㔼局報告 H.IL. Curtis 氏等の論文を駁す）

\begin{tabular}{|c|c|c|c|}
\hline 會 員 & 木 & 村 & 介 \\
\hline 准 貝 & 相 & 濢 & 常 \\
\hline 同 & 竹 & 內 & \\
\hline
\end{tabular}

(電氣試䠯所第 $\boldsymbol{f}$ 部)

\begin{abstract}
1 粕言
ゴムー硫黃系の㮇電體としての性質の研究は、まだ完了して居らないが、米國標售局の H. L. Cwrtis氏及び外二氏に依つて投表せられた論文が、根本的に誤つて居ると思ふのこCurtis 氏等に 依つて得られた結論によると、コム加硫つ理論を迷路に彷得させる虞があるこ思つたので、敢て、

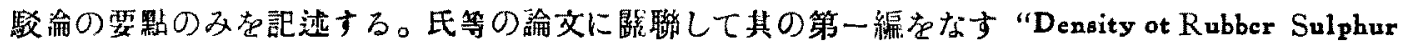
Compoundsに對しても異論を有するが、直接電氣に筑係が無いから、他の雜誌に發表する積りであ 万。
\end{abstract}

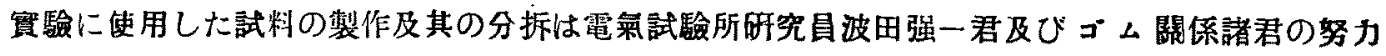
に依䃿ることを附記し謝意を表する。

\section{Curtis 氏等の賽驗結果及び結論の要點}

硫黃とコムの舦合を變じた約二十皬の加硫ゴム試料について、誘電率、力杽、直流抵抗、及び耐

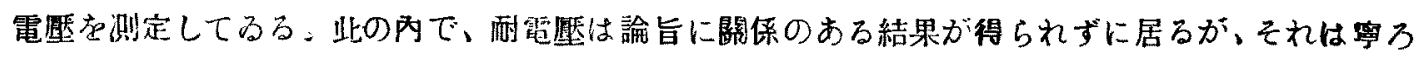

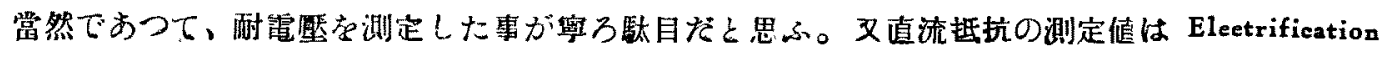

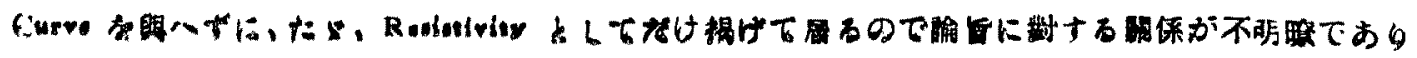


测定值自身隨分不㔚一であるに關はらず、誘電率及び力率の测定結果によつて，或整の先入的観念 があつた筬めか、强て結論と合致するやうに考へて居るに過ぎない。故に直流抵抗及び而電歴は暂 く問題にしない事にする。

試归を $25^{\circ} \mathrm{C} て ゙$ 周波数 1000 の交流で測定し た結果、誘電萃、及び力卒の化合硫黄に對す 万關係ミして第一圖、及び第二圖を得て居る 結論としては次の如くである。

（1）誘電率は化合硫带の曾加と共に始め大ミ なり、10.5\% で最大值な與へ、19\%まで 减少し、それからは $32 \%$ まで徐々に增す。

(2) 力率の化合硫黃による變化も極めて類似 してるる。だ1％％の處に力率の最大值

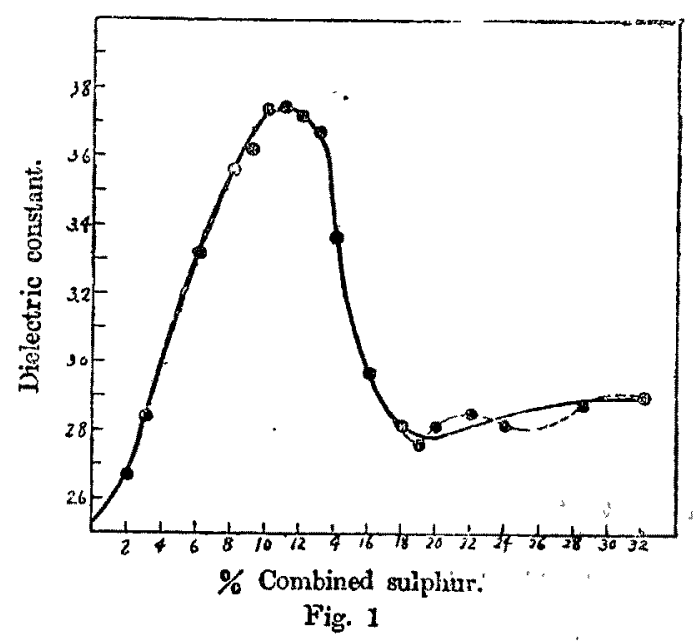
がある。

（う）曲線の方向を變ずる點が、明かに、化合硫黃の $10.5 \%$ 130\% 及び $19 \%$ の處にある。

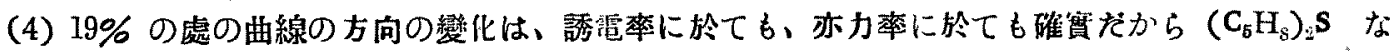
ろ化合物の存在が確かだ。

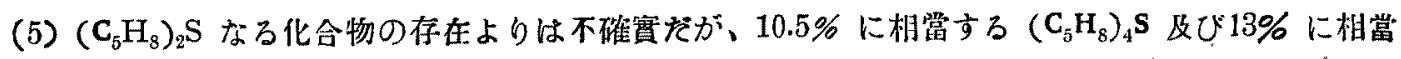
する $\left(\mathrm{C}_{5} \mathrm{H}_{4}\right)_{3} \mathrm{~S}$ もあるらしい。 尚之に加ふるに直流抵抗の曲線の㢣化から出た $\% 6 \%$ 化合硫黄に相當する $\left(\mathrm{C}_{5} \mathrm{H}_{3}\right)_{4} \mathrm{~S}_{3}$ なる化合物

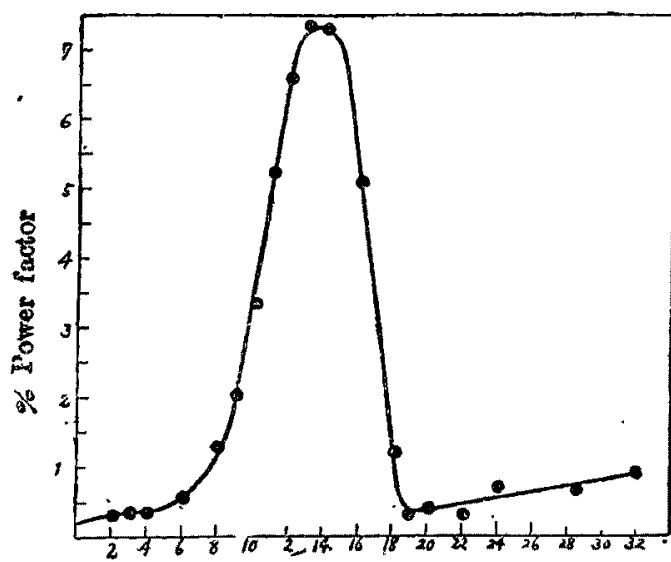

$\because$ Combined sulphur.

Fig. ?
にも未練在殘してるる

\section{3 著者等の實驗結果 $を$ 駁論の要呫}

著者等の䁈驗は、誘電體損失の理諭を探求す るのに行つたもので、試料の厚さ等のquantiative な點に餘り重きを置いてない。のみならず、Cu rtis 氏の論文を䮈ナるのが日的でないから 25C

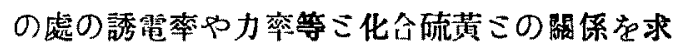
める繁合に、Curtis 氏の結果壁多くの測定點は 得られない。が、䮎論をなずには充分である。 


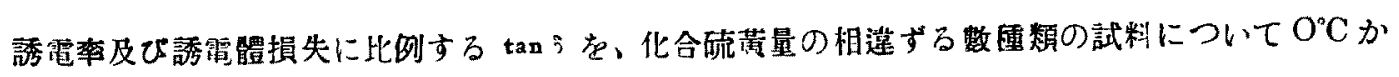

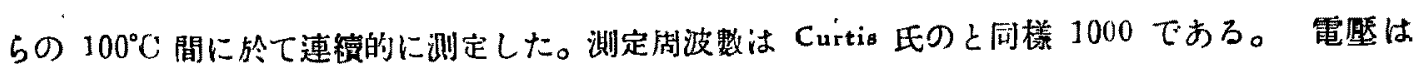
Curtis 氏の論交にも書いてな いが、共に真空管發振器であ ろから、鬼も角、誘電體損失 が䉓庖の二乘に比例する範圍 でおる。

測定の結果は第三圖及第四 圖に示ナ如くである。力率に 略等しい $\tan$ ó の值は溫度に: 對して counter $\mathrm{u}$ 曲線をなし 化合硫黃の增ナのミ共に溫度 の高い方へ移動してゆく。誘 電率は理論的に云つて $\tan$ 济

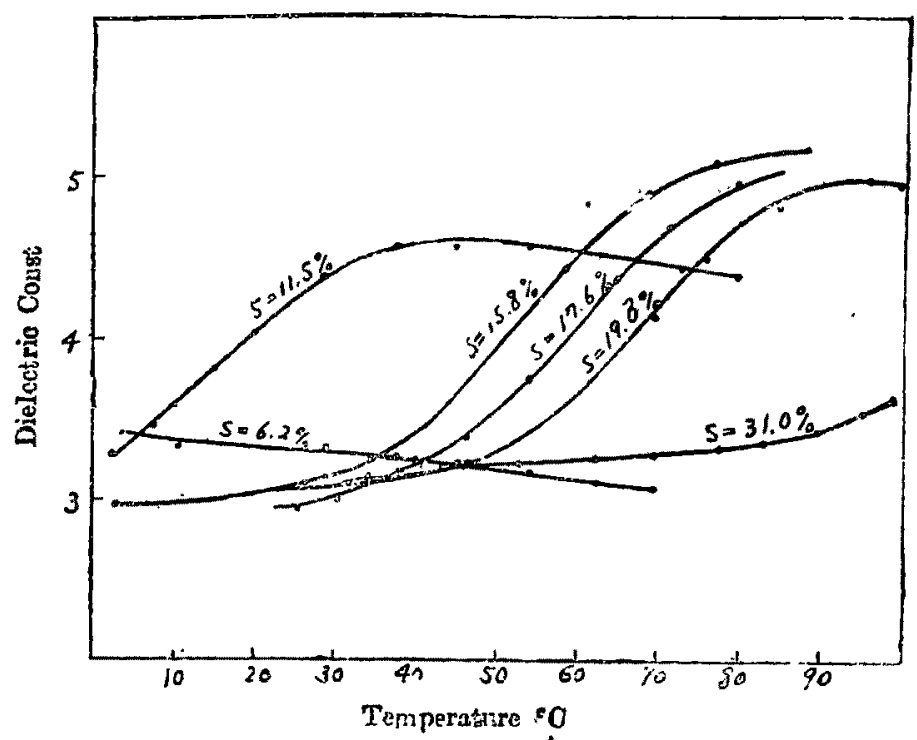
Fig. 3

counte ロを呈ナろ溫度の範圍 で急激な增加をなすのである が、賽驗的にも正しくそうな つて居つて、此の急增す万個 所は化合硫带の增加につれ $\tan \delta$ 曲線と共に溫度の高い方 八移動与号然も此の移顽は 化合硫黄量の變化に龂して滑 かに連櫝的であつて、其の間 に少しも䉥變する處がな。

斯かる曲線群を一定溫度の 處で切れば、誘笔奉や $\tan \delta$ o 化合硫黃量に影す万關䋆が

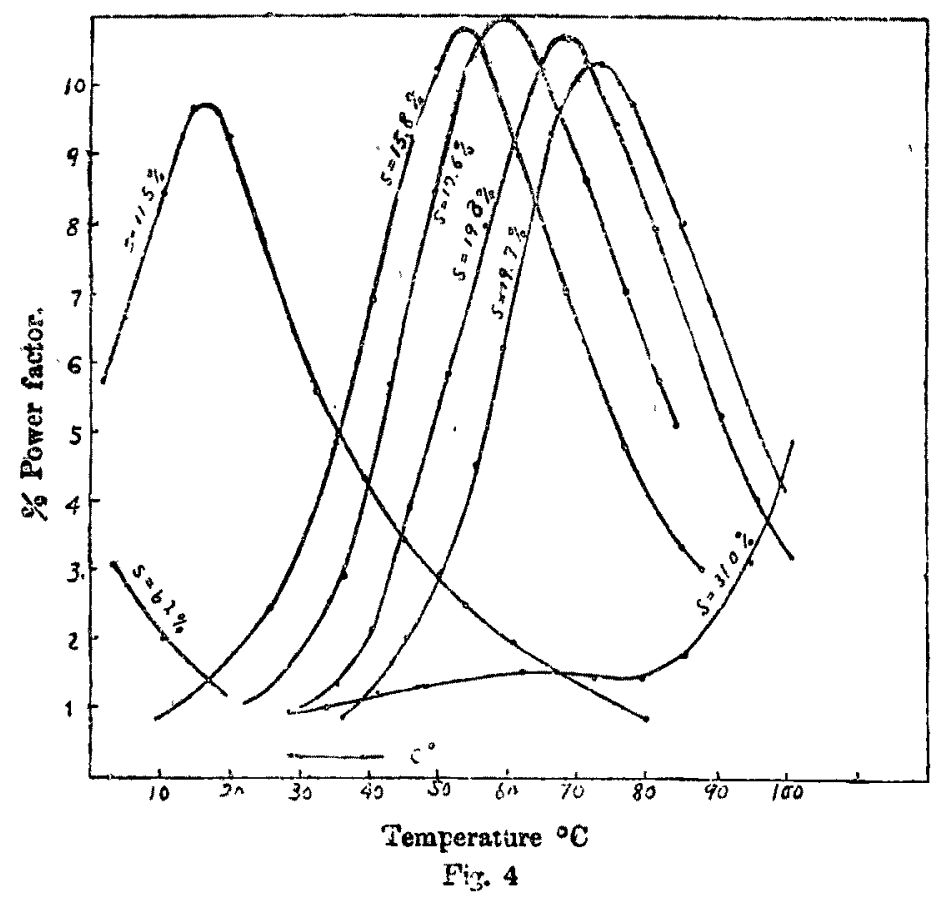

Curtis 比等の求めた曲線のよ5に counter uになるのは学然な事である。然6此の曲線仗溫度の

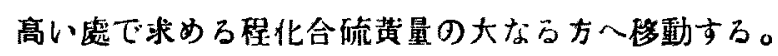




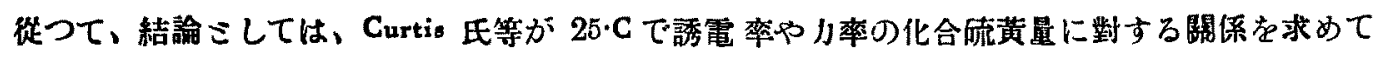

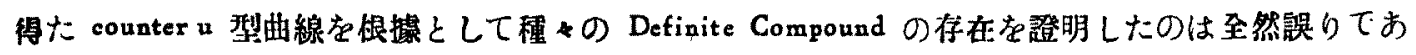
つて、25 C と限定せず、测定する溫度が上下に愁化すれば無數の Definite Componnd の存在を承 認しなけれでならない。故に、扒硫現象は連粗的であつて、何等 Definite compound を作らず

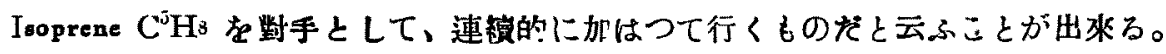

誘電得及 $\tan \delta$ の最大值が Curtis 氏の测定秥果より大になつて居るのは原料の相違にも农らう が主こして硫化操作の相違であらうと思ふ，硫化作用の相違に依る影篦は何れ後日報告する機會 があるであらう。

及、誘電率及び力來が、一旦、減少しきつてから更に僅かなから增してゆくのは、さもあるべき であらう。此の點は今少しくQuantitativeに、正確な實驗をしてから報告する。 